\title{
The first record of Monogenea (Plathelminthes) parasitic on char (Salmonidae: Salvelinus) from Kronotsky Lake (Kamchatka Peninsula), Russia
}

\author{
S.G. Sokolov', I.I. Gordeev ${ }^{2}$ \\ ${ }^{I}$ The Center of Parasitology IPEE RAS, Leninskyi Prospect 33, Moscow 119071 Russia. \\ E-mail:sokolovsg@mail.ru \\ ${ }^{2}$ Russian Federal Research Institute of Fisheries and Oceanography (VNIRO), Verkhnaya Kras- \\ noselskaya Str. 17, Moscow 107140, Russia. \\ E-mail: gordeev@vniro.ru
}

ABSTRACT: Monogeneans are recorded as parasites of fishes in Kronotsky Lake for the first time. Salmonchus sp., Gyrodactylus birmani and Gyrodactylus sp. were found in char. Salmonchus sp. is similar to Salmonchus alaskensis (Price, 1937) and Salmonchus grumosus (Pugachev, 1984), but cannot be unambiguously identified as one of them. Gyrodactylus sp. is similar to Gyrodactylus brachymystacis Ergens, 1978 sensu You et al., 2006 in many features but different in details of the marginal hook sickle morphology. How to cite this article: Sokolov S.G., Gordeev I.I. 2014. The first record of Monogenea (Plathelminthes) parasitic on char (Salmonidae: Salvelinus) from Kronotsky Lake (Kamchatka Peninsula), Russia // Invert. Zool. Vol.11. No.2. P.353-359.

KEY WORDS: Salmonchus, Gyrodactylus birmani, Salvelinus albus, Salvelinus shmidti, Kamchatka Peninsula, Kronotsky Lake.

\section{Первые данные о моногенеях гольцов (Salmonidae: Salvelinus) 03. Кроноцкое (Камчатка)}

\section{С.Г. Соколов ${ }^{1}$, И.И. Гордеев ${ }^{2}$}

\footnotetext{
${ }^{1}$ Центр паразитологии ИПЭЭ РАН, Ленинский проспект 33. Москва 119071, Россия.

${ }^{2}$ Всероссийский институт рыбного хозяйства и океанографии (ВНИРО), ул. Верхняя Красносельская 17, Москва 107140, Россия.
}

РЕЗЮМЕ: Моногенеи впервые отмечаются для фауны паразитов рыб оз. Кроноцкое. У гольцов отмечены Salmonchus sp., Gyrodactylus birmani и Gyrodactylus sp. Salmonchus sp. сходен с Salmonchus alaskensis (Price, 1937) и Salmonchus grumosus (Pugachev, 1984), но не может быть однозначно отнесен ни к одному из них. Gyrodactylus sp. по многим признакам сходен с G. brachymystacis Ergens, 1978 sensu You et al., 2006 от лососевых рыб Китая, но отличается деталями строения собственно крючка краевых крючьев.

Как цитировать эту статью: Sokolov S.G., Gordeev I.I. 2014. The first record of Monogenea (Plathelminthes) parasitic on char (Salmonidae: Salvelinus) from Kronotsky Lake (Kamchatka Peninsula), Russia // Invert. Zool. Vol.11. No.2. P.353-359.

КЛЮЧЕВЫЕ СЛОВА: Salmonchus, Gyrodactylus birmani, Salvelinus albus, Salvelinus shmidti, Камчатка, оз. Кроноцкое. 

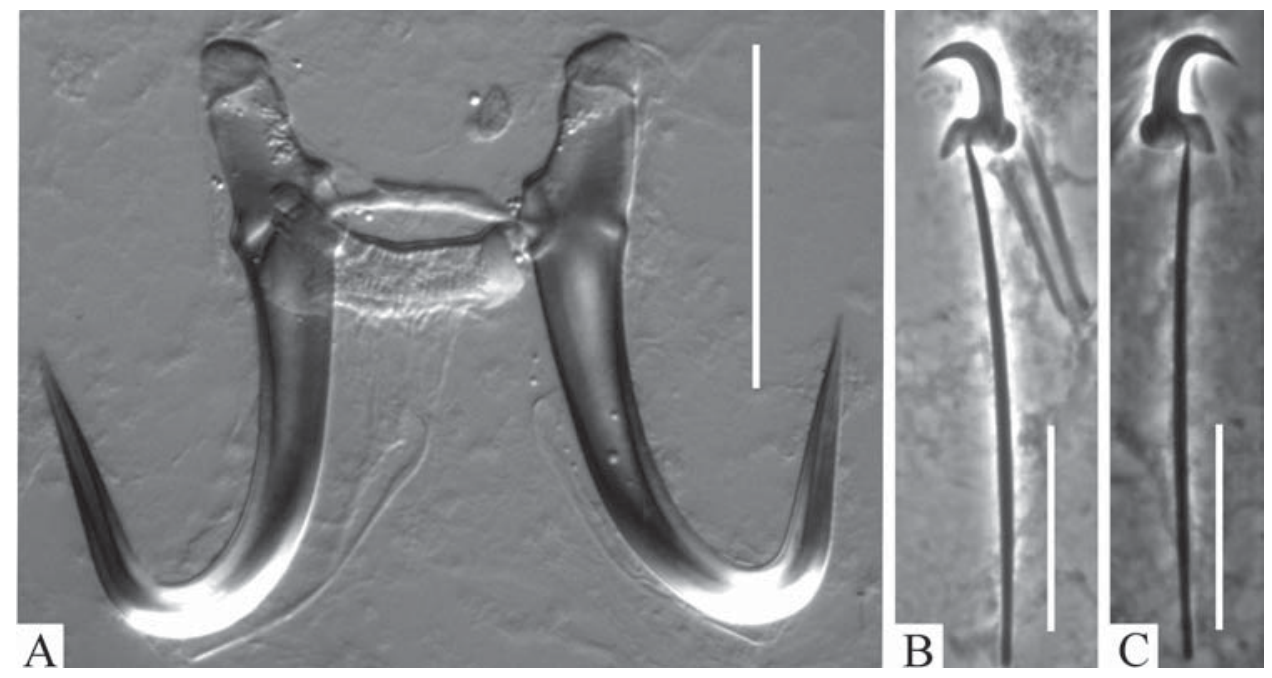

Fig. 1. Gyrodactylus birmani.

A - hamuli; B, C - marginal hooks. Scale bars: A $-45 \mu \mathrm{m}$; B, C $-15 \mu \mathrm{m}$.

Рис. 1. Gyrodactylus birmani.

А - срединные крючья; В, С - краевые крючья. Масштаб: А -45 мкм; В, С -15 мкм.

\section{Introduction}

Kronotsky Lake is the largest area of freshwater in the Kamchatka Peninsula, Russia. The ichthyofauna of this lake comprises resident sockeye salmon (kokanee salmon) Oncorhynchus nerka kennerlyi Suckley, 1861 and three species of char with ambiguous taxonomical position: Salvelinus albus Glubokovsky, 1977, S. cronocius Viktorovsky, 1978 and S. shmidti Viktorovsky, 1978. There are many sources where different authors have diametrically opposed opinions about the systematic position of these species (Victorovsky, 1978; Savvaitova, 1989; Chereshnev et al., 2002; Ostberg et al., 2009 etc). Salvelinus cronocius and S. shmidti are endemic in this lake. The Kronotskaya River is the only river that takes its source from the lake and connects the lake with the Kronotsky Gulf of the Pacific Ocean. Fast and turbulent rapids are a natural obstacle for fishes travelling upstream to the lake. According to Victorovsky (1978), Parensky et al. (2004) and other authors, source and the upper part of the Kronotskaya River are inhabited by resident $S$. malma (Walbaum, 1792) and a peculiar dwarf form of S. malma (Pavlov et al, 2012).

Repeated investigations of the parasitofauna of the Kronotsky fishes reliably recorded 21 species of parasites of different taxa (Zschokke \& Heitz, 1914; Kurenkov, 1977; Butorina et al., 1980, 2008; Butorina, 2003; Atrashkevich et al., 2005), but no monogeneans were found. At the same time representatives of this group of ectoparasitic flatworms are regularly found on salmonid fish from other water bodies of the Kamchatka Peninsula (Konovalov, 1971; Pugachev, 1983; Butorina et al., 2011; Busarova, 2012; etc). The present work records data on monogeneans of the Kronotsky Lake.

\section{Materials and methods}

Seven individuals of $S$. albus (Fork length, $\mathrm{FL}=435-666 \mathrm{~mm}), 22$ individuals of $S$. shmidti ( $\mathrm{FL}=206-446 \mathrm{~mm}$ ) and 1 individual of S. cronocius $(\mathrm{FL}=580 \mathrm{~mm})$ from the south-east part of the Kronotsky Lake $\left(54^{\circ} 43^{\prime} 0.6^{\prime \prime} \mathrm{N}\right.$; $160^{\circ} 21^{\prime} 45.5^{\prime \prime}$ E) were examined from June 20 to August 15, 2011. Monogeneans were found only in S. albus and S. shmidti. All monogenean specimens were mounted in glycerin-gelatin, following Gussev 

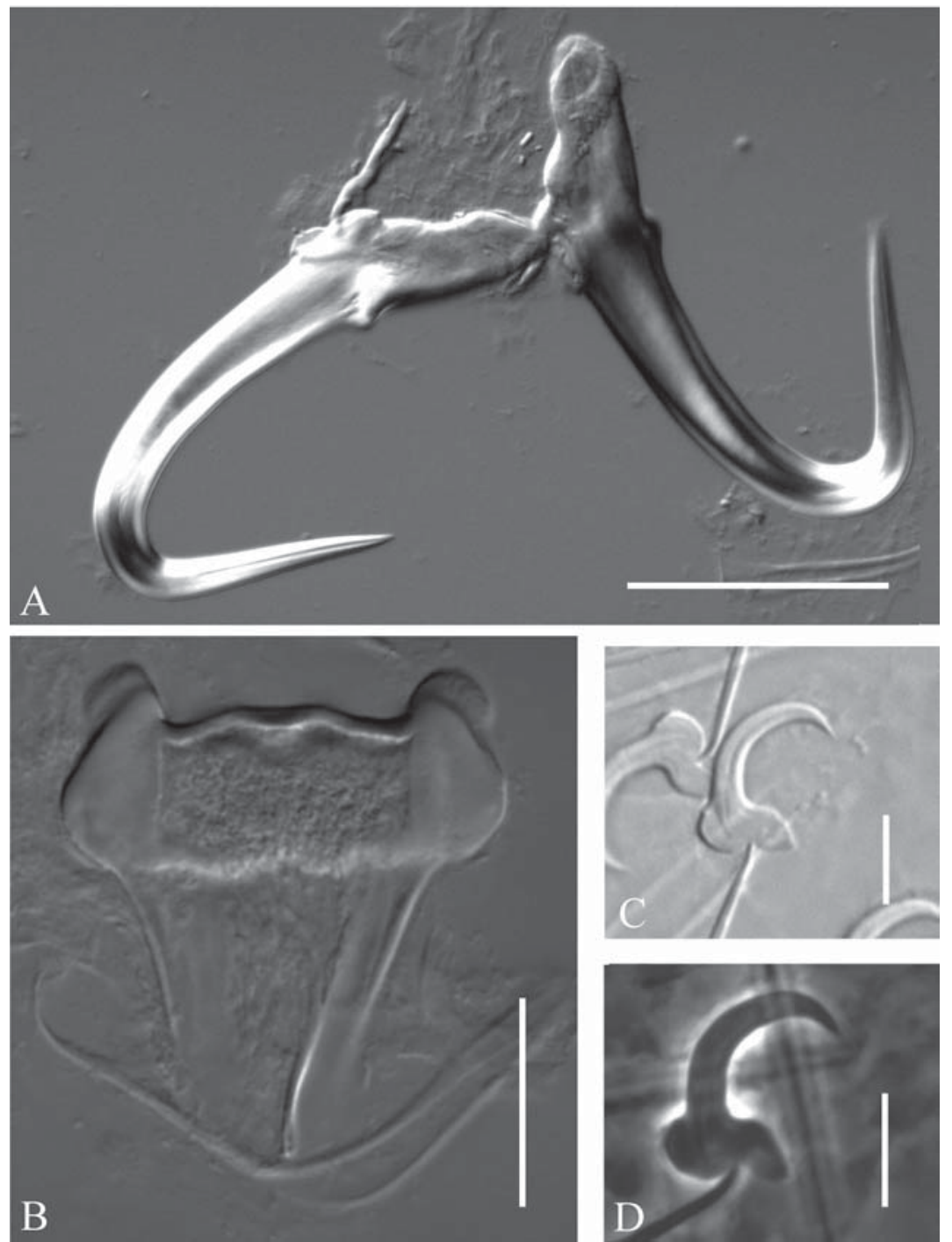

Fig. 2. Gyrodactylus sp.

A - hamuli; B - ventral bar; C, D - marginal hook sickles. Scale bars: A $-40 \mu \mathrm{m}$; B $-17 \mu \mathrm{m}$; C, D $-6 \mu \mathrm{m}$. Рис. 2. Gyrodactylus sp.

A - срединные крючья; В - брюшная соединительная пластинка; C, D - собственно крючки краевых крючьев. Масштаб: $\mathrm{A}-40$ мкм; $\mathrm{B}-17$ мкм; $\mathrm{C}, \mathrm{D}-6$ мкм.

(1983), and were studied using a research microscope with phase-contrast and DIC.

Dimensions of the hard parts of the haptors of monogeneans of the genus Gyrodactylus Nordmann, 1832 were obtained in accordance with Ergens (1985), with the following proposed by Shinn et al. (2004): marginal hook sickle distal width and marginal hook sickle aperture distance. The measurements and termi- nology of sclerotized structures of Salmonchus sp. are given according to Pugachev (1984).

\section{Results and discussion}

The monogeneans Gyrodactylus birmani Konovalov, 1967, Gyrodactylus sp. and Salmonchus sp. (Table 1; Figs. 1-4) were found in char from Kronotsky Lake. Haptor hard parts of 
Table 1. Occurrence of monogeneans in char in Kronotsky Lake. Таблица 1. Встречаемость моногеней у гольцов озера Кроноцкое.

\begin{tabular}{|c|c|c|c|}
\hline \multirow{2}{*}{$\begin{array}{l}\text { Monogeneans/ } \\
\text { Виды } \\
\text { моногеней }\end{array}$} & \multirow[t]{2}{*}{$\begin{array}{l}\text { Site of infection/ } \\
\text { Локализация }\end{array}$} & \multicolumn{2}{|c|}{$\begin{array}{c}\text { Hosts and indexes of infection: prevalence (P), } \\
\text { infection intensity (I)/ Хозяин и показатели } \\
\text { зараженности: экстенсивность (Р), } \\
\text { интенсивность (I) }\end{array}$} \\
\hline & & 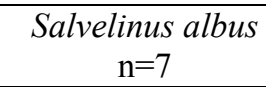 & $\begin{array}{c}\begin{array}{c}\text { Salvelinus shmidti } \\
\mathrm{n}=22\end{array} \\
\end{array}$ \\
\hline Salmonchus sp. & gills/ жабры & - & $\begin{array}{c}\text { (P) in } 2 \text { from } 22(9.1 \%) \\
\text { (I) } 1-2\end{array}$ \\
\hline $\begin{array}{l}\text { Gyrodactylus } \\
\text { birmani }\end{array}$ & $\begin{array}{l}\text { fins, nasal fossae/ } \\
\text { плавники, } \\
\text { носовые ямки }\end{array}$ & $\begin{array}{l}\text { (P) in } 5 \text { from } 7 \\
\text { (I) } 6-109\end{array}$ & $\begin{array}{l}\text { (P) in } 3 \text { from } 22 \\
(13.6 \%) \\
\text { (I) } 3-16\end{array}$ \\
\hline Gyrodactylus sp. & fins/ плавники & - & $\begin{array}{l}\text { (P) in } 1 \text { from } 22(4.5 \%) \\
\text { (I) } 1\end{array}$ \\
\hline
\end{tabular}

Gyrodactylus sp. are as follows: total length of hamuli 86 and $89 \mu \mathrm{m}$, root $-34 \mu \mathrm{m}$, shaft -66 and $67 \mu \mathrm{m}$, point $-44 \mu \mathrm{m}$; ventral bar $-37 \times$ $46 \mu \mathrm{m}$, ventral bar membrane length $-23 \mu \mathrm{m}$, marginal hook total length $-46-47 \mu \mathrm{m}$, marginal hook sickle length $-10 \mu \mathrm{m}$, length of base of marginal hook sickle $-3 \mu \mathrm{m}$, width of base of marginal hook sickle - 6-7 $\mu \mathrm{m}$, marginal hook sickle distal width $-8 \mu \mathrm{m}$ and marginal hook sickle aperture distance $-9 \mu \mathrm{m}$. Edge of marginal hook sickle with two bends (in middle part of sickle shaft and on the boundary of sickle point and sickle shaft) (Fig. 2, 3).

Only one of the three found specimens of Salmonchus sp. was adult. Unfortunately, its dorsal and ventral anchors were not located strictly lateral on the slide. Dorsal anchors: inner length -87 and $94 \mu \mathrm{m}$, outer length -
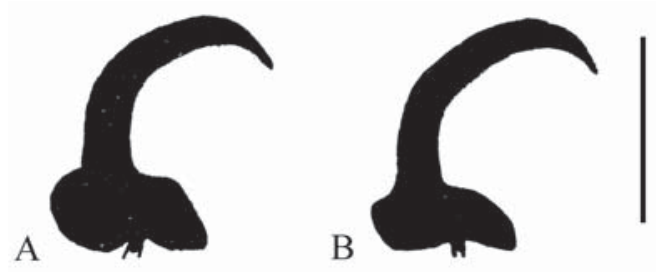

Fig. 3. Marginal hook sickles.

A - Gyrodactylus sp.; B - G. brachymystacis Ergens, 1978 sensu You et al., 2006 (after You et al., 2006). Scale bar $8 \mu \mathrm{m}$.

Рис. 3. Собственно крючки краевых крючьев. A - Gyrodactylus sp.; B - G. brachymystacis Ergens, 1978 sensu You et al., 2006 (из: You et al., 2006). Масштаб 8 мкм.
109 and $112 \mu \mathrm{m}$, length of main part -72 and $78 \mu \mathrm{m}$, blade -36 and $33 \mu \mathrm{m}$. Ventral anchors: inner length -68 and $70 \mu \mathrm{m}$, outer length -95 and no data (broken), length of main part - 61 and $74 \mu \mathrm{m}$, blade -40 and $39 \mu \mathrm{m}$. Marginal hooks: total length $-16-17 \mu \mathrm{m}$, length of handle $-8-9 \mu \mathrm{m}$. Size of connecting bar $-26 \times 44$ $\mu \mathrm{m}$. Tube of copulatory organ $104 \mu \mathrm{m}$ long, supporting apparatus $84 \mu \mathrm{m}$ long.

Gyrodactylus birmani in the water bodies of the Kamchatka Peninsula was recorded mainly as a parasite of Dolly Varden (Konovalov, 1971; Butorina et al., 1980 etc). Butorina (2003) recorded this parasite from $S$. albus from the Azabache Lake and Karmanova (1998) found this parasite on Pacific salmon parr in the Paratunka River basin.

In the Holarctic region more than 15 species of the genus Gyrodactylus show a specifity for salmonid fish (Ergens, 1985; Beverley-Burton, 1984; Ogawa, 1986; Moravec, 2004; Malmberg et al., 2007; Kuusela et al., 2008 etc). Moreover, non-specific species of Gyrodactylus are also found in these fishes, and their obligatory hosts are fishes from other families. But in Kronotsky Lake, its feeders and in the upper reaches of the Kronotskaya River there are only char and kokanee salmon (Victorovsky, 1978 etñ). Thus, the Gyrodactylus sp. recorded by us could have only salmonid fish as the obligatory hosts. Among species from the genus Gyrodactylus that are host-specific for salmonid fish only $G$. lenoki Gussev, 1953, G. asiaticus Ergens, 1978 and G. 

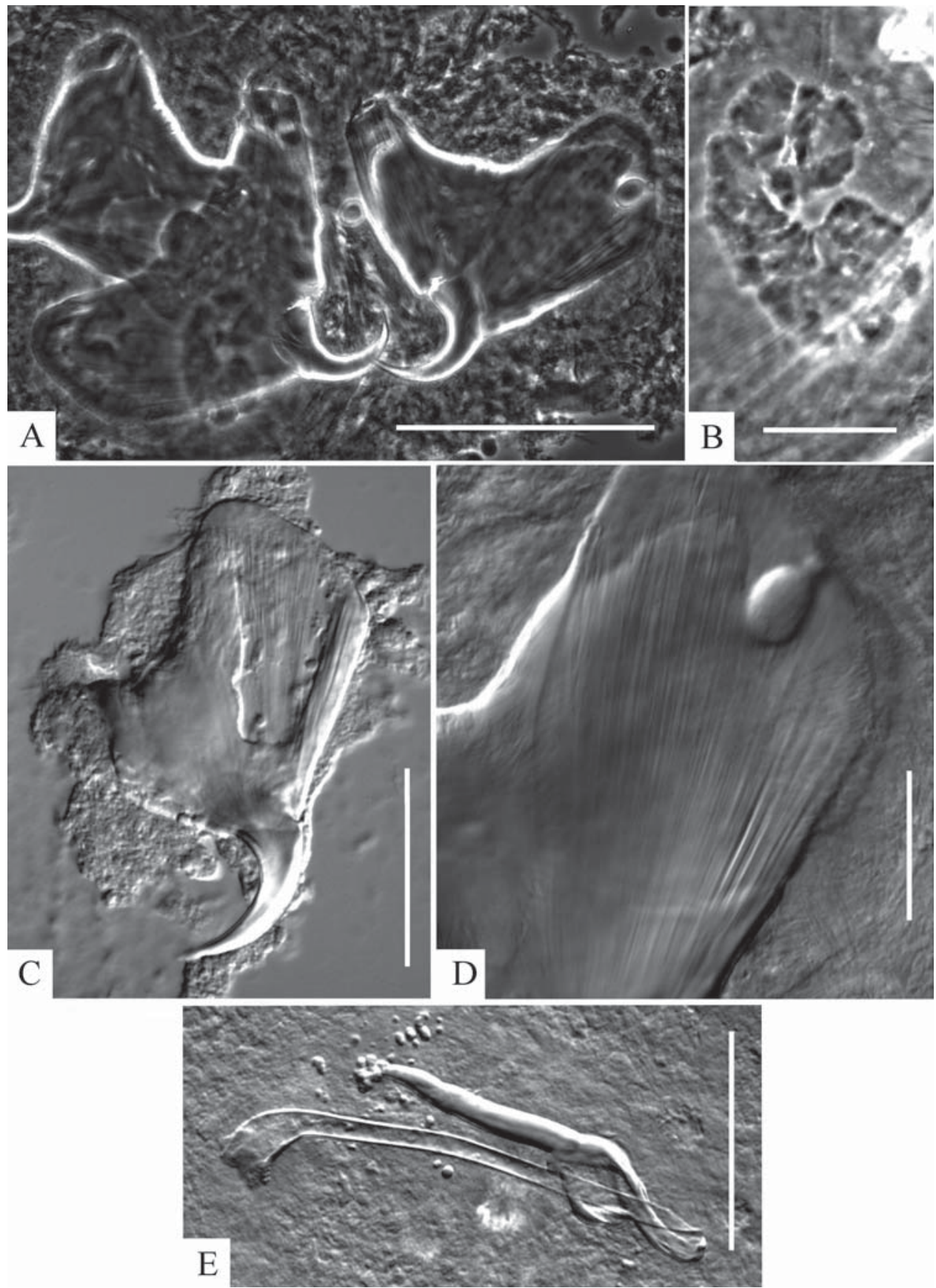

Fig. 4. Salmonchus sp.

A - dorsal anchors; B - connecting bar; C - ventral anchor; D - surface of basal part of dorsal anchor; E - copulatory organ. Scale bars: A $-80 \mu \mathrm{m} ; \mathrm{B}, \mathrm{D}-20 \mu \mathrm{m} ; \mathrm{C}-45 \mu \mathrm{m}$; E $-50 \mu \mathrm{m}$.

Рис. 4. Salmonchus sp.

A - спинные срединные крючья; В - соединительная пластинка; C - брюшной срединный крючок; D поверхность базальной части спинного срединного крючка; Е - копулятивный орган. Масштаб: А -80 мкм; $\mathrm{B}, \mathrm{D}-20$ мкм; $\mathrm{C}-45$ мкм; $\mathrm{E}-50$ мкм. 
brachymystacis Ergens, 1978 sensu You et al., 2006 have edge of marginal hook sickles with two bends. With regard to the length and configuration of the marginal hook sickle, the length of the hamuli and its other dimensions, and the shape and size of the ventral bar, Gyrodactylus sp. is similar to G. branchymystacis Ergens, 1978 sensu You et al., 2006, that is recorded as a parasite of Parasalmo mykiss (Walbaum, 1792) and Brachymystax lenok (Pallas, 1773) in China (You et al., 2006, 2008; Sun et al., 2008). However, the marginal hook sickles of Gyrodactylus sp. have a larger base and, accordingly, a narrower aperture in comparison with G. brachymystacis Ergens, 1978 sensu You et al., 2006 (Fig. 3). There are differences between these parasites in the shape of the hamulus root, but they are not significant. Gyrodactylus sp. may be a new species, but this could not be confirmed because the sample of specimens of Gyrodactylus sp. was too small. In turn, taxonomic identity of $G$. brachymystacis sensu You et al., 2006 and G. brachymystacis Ergens, 1978 s. str. is very doubtful due to differences between these parasites in the shape of the marginal hook sickle. The drawings of Ergens $(1978,1985)$ and the holotype photograph in You et al. (2006) show that the edge of marginal hook sickles of G brachymystacis s. str. smoothly rounded.

Salmonchus sp. is similar to Salmonchus alaskensis (Price, 1937) and S. grumosus (Pugachev, 1984) on morphology of the copulatory organ, connecting bar, shape of anchors and striation of their basal parts, but could not be unambiguously identified as one of them. Shape of the proximal part copulatory organ's tube and little length marginal hook handle make Salmonchus sp. similar to $S$. alaskensis. At the same time short internal processes of ventral anchors make this parasite similar to S. grumosus. Unfortunately, we could not found fan-shaped plates which are of great taxonomical importance (Gussev, Pugachev, 1985). Only one species from genus Salmonchus Spassky et Roytman, 1958 - S. alaskensis was earlier found in fishes of the Peninsula (Konovalov, 1971; Butorina et al., 1980; Sokolov, 2009; etc).
To date, including results of this paper, 15 species and non-identified monogeneans from families Tetraonchidae and Gyrodactylidae, have been recorded in salmon (mikizha, char and Pacific salmon), grayling, cyprinids, sticklebacks and flounders (juvenile starry flounder) from the inner waters of the Kamchatka Peninsula (Akhmerov, 1954; Konovalov, 1971; Sokolov, 2010a, b etc). Moreover, migratory mikizha and Pacific salmon from the lower reaches of Kamchatka west coast rivers are noted as hosts of an oceanic species of gyrodactylid, Laminiscus strelkowi Bychowsky et Poljansky, 1953 (Konovalov, 1971; Sokolov, 2005).

\section{Acknowledgments}

The study was carried out thanks to a cooperative agreement between the Kronotskii State Biosphere Reserve, IPEE RAS and FSUE "VNIRO".

\section{References}

Akhmerov A.Kh. 1954. [On parasitofauna of fishes from Kamchatka River] // Trudy problemnykh i tematicheskikh soveshchaniy. Vol.4. P. 89-98 [in Russian].

Atrashkevich G.I., Orlovskaya O.M., Mikhailova E.I., Frolov S.V., Romanov N.S., Repin M.Yu. 2005. [Helminths of salmonids from Kronotsky Lake (Kamchatka)] // Materialy II Mezhregionalnoy nauchnoy conferentsii "Parazitologicheskie issledovanija v Sibiri i Dal'nem Vostoke". Novosibirsk: Art-Avenyu Press. P.8-10 [in Russian].

Beverley-Burton M. 1984. Monogenea and Turbellaria // L. Margolis, Z. Kabata (eds.). Guide to the Parasites of Fishes of Canada. Part I. Canadian Special Publication of Fisheries and Aquatic Sciences No.74. 209 pp.

Busarova O.Yu. 2012. [Parasites of chars from Kamchatka (Salmonidae: Salvelinus): fauna, ecology]. Saarbrucken: Lap Lambert Academic Publ. 182 pp. [in Russian].

Butorina T.E. 2003. [Parasite fauna of ecologically equivalent species and ecotypes of alpine chars in water bodies of Kamchatka] // Sibirskiy Ekologicheskiy Zhurnal. Vol.10. P.279-287 [in Russian].

Butorina T.E., Busarova O.Yu, Ermolenko A.V. 2011. [Parasites of chars (Salmonidae: Salvelinus) of Holarctic]. Vladivostok: Dal'nauka Publ. 281 pp. [in Russian].

Butorina T.E., Pugachev O.N., Khokhlov P.P. 1980. [Some aspects of ecology and zoogeography of chars from genus Salvelinus in Pacific ocean basin] // Populyatsionnaya biologiya i systematica lososevykh. P.82-96 [in Russian]. 
Butorina T.E., Shedko M.B., Gorovaya O.Yu. 2008. Specific features of ecology of chars of the genus Salvelinus (Salmonidae) from the basin of Lake Kronotskoe (Kamchatka) according to parasitological data // Journal of Ichthyology. Vol.48. P.622-636.

Chereshnev I.A., Volobuev V.V., Shestakyv A.V., Frolov S.V. 2002. [Salmonoid fishes in Russian North-East]. Vladivostok: Dal'nauka Publ. 496 pp. [in Russian].

Ergens R. 1978. Two new species of Gyrodactylus (Monogenoidea) from mongolian Brachymystax lenok (Pallas) // Folia Parasitologica. Vol.25. P.79-81.

Ergens R. 1985. [Order Gyrodactylidea] // O.N. Bauer, A.V. Gussev (eds.). Opredelitel' parazitov presnovodnykh ryb fauny SSSR. Leningrad: Nauka Publ. Vol.2. P.269-347 [in Russian].

Gussev A.V. 1983. [Method of collection and elaboration of fish-parasitic monogenean material]. Leningrad: Nauka Publ. 47 pp. [in Russian].

Gussev A.V., Pugachev O.N. 1985. [Order Tetraonchidea] // O.N. Bauer, A.V. Gussev (eds.). Opredelitel' parazitov presnovodnykh ryb fauny SSSR. Leningrad: Nauka Publ. Vol.2. P.253-268 [in Russian].

Karmanova I.V. 1998. [Parasites of pacific salmons in epizootic situation of parasitoses in Paratunka River basin (Kamchatka)]. Avtoreferat dissertacii na soiskanie stepeni kandidata biologicheskich nauk. INPA RAN. 23 pp. [in Russian].

Konovalov S.M. 1971. [Differentiation of local stocks of sockeye salmon Oncorhynchus nerka (Walbaum)]. Leningrad: Nauka Publ. 229 pp. [in Russian].

Kurenkov S.I. 1977. [Two reproductively isolated groups of resident sockeye salmon Oncorhynchus nerka kennerlyi (Suskleu) from Kronotsky Lake] // Voprosy Ikhtiologii. Vol.17. P.597-606 [in Russian].

Kuusela J., Ziêtara M., Lumme J. 2008. Description of three new european cryptic species of Gyrodactylus Nordmann, 1832 supported by nuclear and mitochondrial phylogenetic characterization // Acta Parasitologica. Vol.53. P.120-126.

Malmberg G., Collins C.M., Cunningham C.O., Jalali B.J. 2007. Gyrodactylus derjavinoides sp. nov. (Monogenea, Platyhelminthes) on Salmo trutta trutta L. and $G$. derjavini Mikailov, 1975 on S. t. caspius Kessler, two different species of Gyrodactylus - combined morphological and molecular investigations // Acta Parasitologica. Vol.52. P.89-103.

Moravec F. 2004. Metazoan parasites of salmonid fishes of Europe. Prague. Academia Publ. 510 pð.

Ogawa K. 1986. A monogenean parasite Gyrodactylus masu sp.n. (Monogenea: Gyrodactylidae) of salmonid fish in Japan // Bulletin of the Japanese Society of Scientific Fisheries. Vol.52. P.947-950.

Ostberg C.O., Pavlov S.D., Hauser L. 2009. Evolutionary relationships among sympatric life history forms of dolly varden inhabiting the landlocked Kronotsky Lake, Kamchatka, and a neighboring anadromous population // Transactions of the American Fisheries Society. Vol.138. P.1-14.

Parensky V.A., Romanov N.S., Frolov S.V., Nikanorov A.P., Repin M.Yu. 2004. [Kraniological analysis of chars (Salvelinus) of Krinotsky Lake (Kamchatka)] // Sochranenie bioraznoobraziya Kamchatki i prilegayushich morey: Meterialy V naychnoy konferentsii (Petropavlovsk-Kamchatsky, 22-24 November 2004).
Petropavlovsk-Kamchatsky: Kamchatpress Publ. P.280-283 [in Russian].

Pavlov S.D., Pivovarov E.A., Ostberg C.O. 2012. Dwarf char, a new form of chars (the genus Salvelinus) in Lake Kronotskoe // Doklady Biological Sciences. Vol.442. P.20-23.

Pugachev O.N. 1983. [Monogeneas of fresh-water fishes of North-East Asia] // Trudy Zoologicheskogo Instituta AN SSSR. Vol.121. P.22-35 [in Russian].

Pugachev O.N. 1984. [On the fauna of monogeneans of the Tetraonchidae Bychowsky, 1937] // Parazitologiya. Vol.18. P. 30-39 [in Russian].

Savvaitova K.A. 1989. [Arctic chars (structure of population systems, perspectives of economic use)]. Moskva: Agropromizdat Publ. 223 p. [in Russian].

Shinn A.P., Hansen H., Olstad K., Bachmann L., Bakke T.A. 2004. The use of morphometric characters to discriminate specimens of laboratory-reared and wild populations of Gyrodactylus salaris and G. thymalli (Monogenea) // Folia Parasitologica. Vol.51. P.239-252.

Sokolov S.G. 2005. [Review of mikizha Parasalmo mykiss (Osteichthyes: Salmonidae) parasites from Kamchatka] // Invertebrate Zoology. Vol.2. P.35-60 [in Russian, with English summary].

Sokolov S.G. 2009. [First data on parasites of masu salmon Oncorhynchus masou (Salmonidae) in Kamchatka Peninsula] // Bulletin of the North-East Scientific Center, Russia Academy of Sciences Far East Branch. No.1. P.102-105 [in Russian].

Sokolov S.G. 2010a. [New data on helminthes of juvenile starry flounder Platichthys stellatus (Pallas, 1787) (Osteichthyes, Pleuronectidae) inhabiting western Kamchatka Rivers] // Biologia Vnutrennykh Vod. No.1. P.85-91 [in Russian].

Sokolov S.G. 2010b. [Parasites of stickleback fishes (Gasterosteridae) from Utkholok River basin (Northwestern Kamchatka)] // Bulletin of the North-East Scientific Center, Russia Academy of Sciences Far East Branch. No.3. P.56-66 [in Russian].

Sun X., Qiang X., Wang Y., Cone D., You P. 2008. [A newly recorded species of Gyrodactylus (Monogenoidea) in Oncorhynchus mykiss (Walbaum) from Qinling Mountains] // Sichuan Journal of Zoology. Vol.27. P.1146-1148 [in Chinese].

Victorovsky R.M. 1978. [Mechanisms of speciation in chars of Kronotsky Lake]. Moskva: Nauka Publ. 106 pp. [in Russian].

You P., Wang Y., Sun X., Qiang X., Cone D. 2008. Seasonality of Gyrodactylus brachymystacis Ergens on farmed rainbow trout, Oncorhynchus mykiss (Walbaum), in central China, with a report of an infection on wild manchurian trout, Brachymystax lenok (Pallas) // Journal of Fish Diseases. Vol.31. P.941-945.

You P., Yuan B., Yang J., Easy R., Dong Z., Cone D. 2006. Pathogenic infections of Gyrodactylus brachymystacis (Monogenea) on Oncorhynchus mykiss (Walbaum) at a fish farm in the Qinling Mountain region of China // Journal of Fish Diseases. Vol.29. P.313-316.

Zschokke F., Heitz Fr.A. 1914. Endoparasiten aus Salmoniden von Kamtschatka // Revue Suisse de Zoologie. Bd.22. S.195-256.

Responsible editors N.M. Biserova, E.N. Temereva, K.G. Mikhailov 